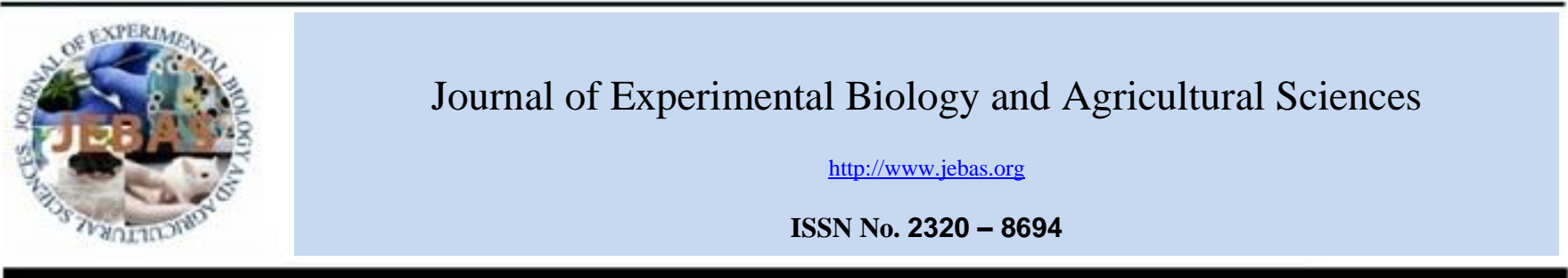

\title{
ZINC BIOFORTIFICATION: A NOVEL STRATEGY FOR IMPROVING HUMAN HEALTH
}

\author{
Ayan Das, S. K. Singh*, Maneesh Kumar, Omkar Kumar \\ Department of Soil Science and Agricultural Chemistry, Institute of Agricultural Sciences, Banaras Hindu University, Varanasi - 221005, India. \\ Received - July 13, 2018; Revision - August 24, 2018; Accepted - September 17, 2018 \\ Available Online - October 5, 2018
}

DOI: http://dx.doi.org/10.18006/2018.6(5).751.762

\section{KEYWORDS}

Zinc biofortification

Human health

Malnutrition

Antinutrients

Phytates

\begin{abstract}
Zinc $(\mathrm{Zn})$ is an essential trace element needed for proper growth of plants, animals and human. The area where there is deficiency of $\mathrm{Zn}$ in the soil is also the area with widespread occurrence of $\mathrm{Zn}$ deficiency in human. Zinc fertilization in the field will not only help in correcting $\mathrm{Zn}$ deficiency in the crop and obtaining better yield and productivity, but will also help in fighting against malnutrition due to $\mathrm{Zn}$ in the population relying on that crop. Various approaches like industrial fortification, food supplementation and dietary diversification are implemented to fight against micronutrient malnutrition. However, these are neither sustainable as well as cost-effective, nor do they target the rural population. Biofortification of $\mathrm{Zn}$ in the grains of staple food crops is a better option to reach the poorest of the poor. However, biofortifying the crops with micronutrients meet up with several challenges. More than $50 \%$ of the $\mathrm{Zn}$ is lost during milling. The remaining fraction of $\mathrm{Zn}$ is also not available to the full extent for intestinal absorption due to presence of some antinutrient factors like phytates. Therefore, the biofortification programmes should aim at engineering $\mathrm{Zn}$ partitioning more to seed endosperm, curbing loss of $\mathrm{Zn}, \mathrm{Fe}$ and other essentials during processing and $\mathrm{Zn}$ profiling of food crops along with $\mathrm{Fe}$ and other nutrients, antinutrients and promoters to get a better crop for a healthy life.
\end{abstract}

* Corresponding author

E-mail: sksingh_1965@rediffmail.com (S. K. Singh)

Peer review under responsibility of Journal of Experimental Biology and Agricultural Sciences.

Production and Hosting by Horizon Publisher India [HPI] (http://www.horizonpublisherindia.in/).

All rights reserved.
All the article published by Journal of Experimental Biology and Agricultural Sciences is licensed under a Creative Commons Attribution-NonCommercial 4.0 International License Based on a work at www.jebas.org.

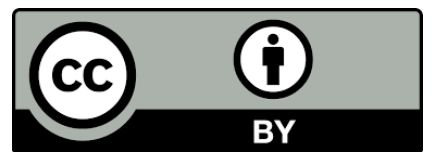




\section{Introduction}

Zinc ( $\mathrm{Zn})$ is an important trace element which is essential for the normal healthy growth of plants, animals and humans. In plants, $\mathrm{Zn}$ is present as a structural constituent or regulatory co-factor of different enzymes and proteins involved in metabolism of carbohydrate, protein and auxin, pollen formation, the maintenance of membranes integrity (Marschner, 1995) and providing tolerance to reactive oxygen species (Cakmak, 2000). Role of $\mathrm{Zn}$ in animals include nucleic acid metabolism (Miller et al., 1967), cell signalling (McNulty \& Taylor, 1999) and apoptosis (Zalewski et al., 1993). Zinc is essential for physiological processes including growth and development (Prasad, 1985), lipid metabolism (Cunnane, 1988), brain and immune function (Prasad, 1985). According to Vidyavati et al. (2016) zinc deficiency associated with various human disorder such as growth retardation in children, spontaneous abortion in pregnant woman, repeated respiratory infections, alopecia, depression lack of concentration, skin infections, diarrhea and oral or genital ulcers. Role of the Fe and $\mathrm{Zn}$ in human nutrition has been clearly demonstrated. World Health Organization has racked $\mathrm{Fe}$ and $\mathrm{Zn}$ deficiency to be $5^{\text {th }}$ and $6^{\text {th }}$ among top ten major causes of illness and disease in developing countries.

In India, the per capita availability of agricultural land (0.12 ha) and net cultivated area (141.58 ha) is shrinking continuously and as a result pressure for enhancing food grain production is a prime need (Anonymous, 2013). Therefore, any factors, such as zinc deficiency, which can prevent crops from attaining their potential yield, need to be addressed. Identifying the main areas of $\mathrm{Zn}$-deficient soils and crops and treating them with $\mathrm{Zn}$ fertilizers to correct the deficit to the crops, or growing more $\mathrm{Zn}$-efficient crops which can tolerate lower available concentrations of $\mathrm{Zn}$ in soil needed to maximize food production. Hafeez et al. (2013) reported that zinc deficiencies associated with the growth retardation, reduction in tillers number, leaves size while it increases chlorosis and crop maturity period. Further, these researchers also reported the role of $\mathrm{Zn}$ in cellular functions and human immune system, due to its insufficient intake, human body will suffer from hair and memory loss, skin problems and weakness in body muscles.

Recently, there is a shift in micronutrient fertilization strategy to avail twin benefits of maximization of crop productivity and producing micronutrient ( $\mathrm{Fe}$ and $\mathrm{Zn}$ ) rich food for alleviating micronutrient-related nutritional disorders in humans. Over one billion people worldwide do not get enough food (FAO, 2009). However, a far more estimate of two billion people suffer from a 'hidden hunger' of micronutrient malnutrition (Kennedy et al., 2003). Increasing the density of $\mathrm{Zn}$ in staple food crops is considered to be a big global challenge of this century. It is estimated (WHO, 2007) that almost $27 \%$ of total population in India is affected by various $\mathrm{Zn}$ deficiency related disorders such as poor immune system, diarrhea, poor physical and mental growth. Children are more prone to Zinc deficiency which causes about $4.4 \%$ of the total child deaths in the world (Black, 2003). Biofortification of $\mathrm{Zn}$ is an approach aiming to increase $\mathrm{Zn}$ concentrations in the edible parts of plants through crop breeding or the use of biotechnology or through agronomic practices as well (Cakmak, 2008). Biofortification associated with the increasing $\mathrm{Zn}$ concentration up to $40-60 \mathrm{mg} \mathrm{kg}^{-1}$ in cereals grain. It can be achieved either by the application of $\mathrm{Zn}$ fertilizers or developing crop varieties that has ability to concentrate more $\mathrm{Zn}$ in edible portions. This approach of $\mathrm{Zn}$ delivery is considered to be more economical and effective strategy to the rural populations in developing countries (Nestel et al., 2006; Mayer et al., 2008). This article aimed at presenting information's on various approaches of Zn biofortification and bioavailability of fortified zinc for improving human health.

\section{Causes of $\mathrm{Zn}$ Deficiency in Soil}

The major causes which may contribute to the occurrence of $\mathrm{Zn}$ deficiency in soil include one or more of the following (Lindsay, 1972):

- Low total Zn concentrations

- Calcareousness

- Peat and muck soils

- $\mathrm{pH}$ towards alkalinity

- High available $\mathrm{P}$

- Paddy soils

- High sodium, calcium, magnesium and bicarbonate concentrations.

The plant-available forms of $\mathrm{Zn}$ in soils are free ions $\left(\mathrm{Zn}^{2+}\right.$ and $\mathrm{ZnOH}^{+}$). The $\mathrm{pH}$ dependency of the $\mathrm{Zn}$ solubility is governed by:

$$
\begin{gathered}
\text { Soil- } \mathrm{Zn}+2 \mathrm{H}^{+} \rightleftharpoons \mathrm{Zn}^{2+} \quad \log \mathrm{K}^{0}=5.8 \\
\text { Or, } \\
\log \mathrm{Zn}^{2+}=5.8-2 \mathrm{pH}
\end{gathered}
$$

Therefore, $\mathrm{Zn}^{2+}$ solubility decreases 100 times with increase in 1 unit of pH (Lindsay, 1979).

During green revolution, increasing yield by intensive high input responsive agriculture helped in achieving food security but ignored soil health. The discovery of widespread $\mathrm{Zn}$ deficiency 
problems is due to the shift from traditional agriculture to growing modern, high-yielding, input responsive plant. These new crop varieties are much more susceptible to $\mathrm{Zn}$ deficiency than the traditional crops. Thereby, to maximize food production and increase the productivity of the land, zinc deficiency needs to be addressed. For correcting the $\mathrm{Zn}$ deficiency, different $\mathrm{Zn}$ fertilizers are available in the market as presented in table 1 (Alloway, 2008a; Brouwer, 2010; Das \& Green, 2013). These fertilizers could be applied by various methods such as broadcasting, banding, foliar sprays, seed treatments and root dipping of rice seedlings before transplanting (Mortvedt \& Gilkes, 1993). Cheated forms of $\mathrm{Zn}$, such as $\mathrm{Na}_{2} \mathrm{Zn}$-EDTA are also used as foliar application on high value crops (Alloway, 2008b).

\section{Zinc Enhances Crop Productivity}

Proper $\mathrm{Zn}$ nutrition of the crop is needed for maintaining crop yield and productivity. Success story in Central Anatolia, Turkey

Table 1 Commonly used $\mathrm{Zn}$ fertilizers

\begin{tabular}{|c|c|}
\hline Compound & $\mathrm{Zn}$ content $(\%)$ \\
\hline \multicolumn{2}{|c|}{ Inorganic compounds } \\
\hline Zinc sulphate monohydrate & 33 \\
\hline Zinc sulphate heptahydrate & 21 \\
\hline Zinc oxysulphate & $20-50$ \\
\hline Zinc oxide & $50-80$ \\
\hline Zinc carbonate & $50-56$ \\
\hline Zinc chloride & 50 \\
\hline Zinc nitrate & 23 \\
\hline Zinc phosphate & 50 \\
\hline Zinc frits & $10-30$ \\
\hline \multicolumn{2}{|c|}{ Organic compounds } \\
\hline Disodium zinc EDTA & $8-14$ \\
\hline Sodium zinc HEDTA & $6-10$ \\
\hline Sodium zinc EDTA & $9-13$ \\
\hline Zinc polyflavonoid & $5-10$ \\
\hline Zinc lignosulphonate & $5-8$ \\
\hline \multicolumn{2}{|c|}{ Fortified fertilizers } \\
\hline Zincated urea & 2 \\
\hline Zincated phosphate (suspension) & 17.6 \\
\hline DAP with $0.5 \%$ Zinc & $18: 46: 0: 0.5$ \\
\hline NPK with $0.5 \%$ Zinc & $10: 26: 26: 0.5$ \\
\hline \multicolumn{2}{|c|}{ Water soluble complex fertilizer } \\
\hline NPK with $3.5 \%$ Zinc-EDTA & $7.6: 23.5: 7.6: 3.5$ \\
\hline \multicolumn{2}{|c|}{ Customized fertilizers } \\
\hline Nutrients & Nutrient content \\
\hline $\mathrm{N}: \mathrm{P}: \mathrm{K}: \mathrm{S}: \mathrm{Zn}$ & $\begin{array}{l}\text { Manufactured by Nagarjuna } \\
\text { fertilizers and chemicals for } \\
\text { Rice crop in Telangana district } \\
\text { of Andhra Pradesh }\end{array}$ \\
\hline
\end{tabular}

Source: ref. Alloway (2008a); Das \& Green (2013); Brouwer (2010)

Journal of Experimental Biology and Agricultural Sciences http://www.jebas.org 
can be taken as an example, where $\mathrm{Zn}$ fertilization has been reported to increase wheat yield dramatically (Cakmak, 2004). Various other reports of positive impact of $\mathrm{Zn}$ application on plant growth are also available in India (Yoshida \& Tanaka, 1969; Yilmaz et al., 1997; Muthukumararaja \& Sriramachandrasekharan, 2012; Mabesa et al., 2013; Imran et al., 2015). With increase in overall zinc deficiency in India from $42 \%$ to $49 \%$ (Singh, 2009) and an estimated yield losses of US \$ 1.5 billion (Singh, 2010) efforts are underway to reduce zinc deficiency in soils. Latest estimate (Shukla et al., 2018) clearly demonstrated that the extent of Zn deficiency in Indian soil is on the path of decline and is currently to a tune of $36.5 \%$. This is because of the awareness among the farmers to apply $\mathrm{Zn}$ fertilizers to seek the twin benefits of increased crop production and improvement in human health.

\section{Zinc Important for Human Health}

A geographical overlap between $\mathrm{Zn}$ deficiency in soil and human (Cakmak, 2010) made Zn deficiency an important issue of concern. Pharmaceutical supplementation, industrial fortification, dietary diversification and biofortification are some of the strategies to fight against micronutrient malnutrition (Meenakshi et al., 2007). Dietary diversification although most effective is impractical in many countries due to lack of wide availability and compliance issues (Galera et al., 2010). Where infrastructure allows, mineral nutrition can be improved using pharmaceutical supplementations (tablet/sachet) or conventional fortification or industrial fortifications. Unfortunately, this strategies also have been largely unsuccessful in developing countries because of high cost involvement and only very few governments can afford such kinds of expensive interventions (Meenakshi et al. 2007; Stein et al. 2007).

However, biofortification targets the rural areas where an estimated $75 \%$ of the poor lives surviving on large amounts of staple foods. After an initial investment in developing biofortified crops, those crops can be adapted to various regions at a low additional cost and are available in the food system, year after year. It is sustainable too. Expected increases in food prices are likely to increase dependence on staple foods (Bouis \& Welch, 2010). Therefore, enhancing the quality of the staple crops holds immense importance.

\section{Biofortification}

Biofortification is the enrichment of the edible parts of the crops with nutrients under consideration through agronomic managements or conventional breeding, transgenic approaches or a combination of these to reach the poor population of the middle and low income countries to fight against malnutrition. Biofortification consists of two approaches: genetic and agronomic approach. However, for a successful biofortification program an integrated approach is needed rather than considering them alone.

\subsection{Genetic Approach}

Breeding for $\mathrm{Zn}$ fortification is a long term process involving identification of the required traits and the most promising parent, crossing and back crossing, environmental stability of the trait and adaptation of the plant to the new environment (Cakmak, 2008). Breeding crops for high $\mathrm{Zn}$ concentration in the edible parts should aim at exploring and exploiting genetic control and molecular physiological mechanisms contributing to higher accumulation of Zn (White \& Broadley, 2005).

Enhancing $\mathrm{Zn}$ uptake from the rhizosphere, translocation to shoots, phloem loading, and remobilization will help in enhancing grain Zn concentration. Under Zn deficient conditions, genes like ZIP1 and ZIP3 in roots, ZIP4 in both roots and shoots (Guerinot, 2000), a homolog GmZIP1 in soybean (Glycine max) nodules (Moreau et al., 2002) are found to be expressed. In rice, various transporters including OsZIP1, OsZIP3 OsZIP4 and OsZIP5 were found to be induced under $\mathrm{Zn}$ deficiency (Ramesh et al., 2003; Ishimaru et al., 2006). Mugineic acid family phytosiderophores (MAs) were proposed to contribute to the acquisition of $\mathrm{Zn}$ besides Fe acquisition in graminaceous plants (Welch, 1995). In wheat (Triticum spp.) and barley (Hordeum vulgare), $\mathrm{Zn}$ deficiency was reported to induce MAs secretion (Zhang et al., 1989; Cakmak et al., 1994). The increased secretion of MAs in rice line RIL46 (Widodo et al., 2010) was also reported. Despite the progress in understanding micronutrient uptake and translocation information about phloem delivery of micronutrients to seeds in different crops is particularly lacking (Waters \& Renuka, 2011). Moreover, a successful breeding program depends upon optimization of the soil available nutrient pools.

Very recently, scientists in Raipur, India have developed a high zinc-enriched variety of rice called "Chhattisgarh Zinc Rice-1" (Press release, 2015).

\subsection{Agronomic Approach}

From the above discussion, it is now evident that for a successful breeding program, it is very important to provide $\mathrm{Zn}$ to the plant through fertilizer application. Proper agronomic approach includes: selection of the proper method of fertilization (soil, foliar, soil + foliar, seed treatment, etc.) along with its proper rate, place and time of application. According to Cakmak (2008) soil and/or foliar applications of $\mathrm{Zn}$ fertilizers found significant in increase $\mathrm{Zn}$ concentrations in grain. Soil + foliar application of $\mathrm{Zn}$ was reported as the most effective method for increasing the grain Zn content in wheat (Yilmaz et al., 1997). Similar reports of foliar 
$\mathrm{Zn}$ applications to be more effective in increasing $\mathrm{Zn}$ concentration in brown rice with an average increase of $2.4,25$ and $32 \%$ by soil, foliar and foliar + soil $\mathrm{Zn}$ application, respectively were shown (Figure1). Foliar $\mathrm{Zn}$ application during early milk stage was reported to be most effective in increasing grain Zn concentration (Mabesa et al., 2013). However, (Wissuwa et al., 2008) reported native soil $\mathrm{Zn}$ status to be the dominant factor than genotype and fertilizer in determining grain $\mathrm{Zn}$ concentrations.

Various other approaches were also tried for enriching the grains with $\mathrm{Zn}$. Alternate wet and dry cycle in paddy field combined with $\mathrm{ZnSO}_{4}$ rather than $\mathrm{Zn}$-EDTA fertilization was demonstrated as an effective method to elevate grain yield and increase $\mathrm{Zn}$ accumulation in rice grains (Wang et al., 2014). Nitrogen (N) and $\mathrm{Zn}$ fertilization had been reported to have a synergistic effect on grain $\mathrm{Zn}$ concentration (Kutman et al., 2010). Possibly by affecting the levels of $\mathrm{Zn}$-chelating nitrogenous compounds or the abundance of $\mathrm{Zn}$ transporters. The use of summer green manures Sesbania aculeate along with $\mathrm{Zn}$ fertilization, irrespective of sources and methods of application was reported to be beneficial for $\mathrm{Zn}$ enrichment in the grains of basmati rice (Singh \& Shivay 2013). Application of biosolids and biosolids+biochar treatments significantly increased the $\mathrm{Zn}$ concentration of most species with beet root showing the greatest increase in the dry weight $\mathrm{Zn}$ concentrations (Gartler et al., 2013). Effect of different agronomic management approaches in increasing $\mathrm{Zn}$ concentrations is enlisted in table 2 .

\subsection{Choice of Crops for Biofortification}

Zinc is unevenly distributed within the plant in the order root $\approx$ shoot >fruit, seed, tuber (Broadley et al., 2012). Thus the concentrations of $\mathrm{Zn}$ are generally higher in root and leafy vegetables crops as compared to the grain, seed, fruit, or tuber crops (White \& Broadley, 2005; Pfeiffer \& Mc Clafferty, 2007; White \& Broadley, 2009). Further, it has been reported that $\mathrm{Zn}$ concentration are generally higher in the legumes seeds as compared to the cereals. In south and south-east Asia, with $90 \%$ of the rice grown and consumed, the normal consumption of rice ranged between 300 to $800 \mathrm{~g}$ per day per person in south and south-east Asia, where $90 \%$ of the rice are grown (Virk et al., 2009). In brown rice, the grain $\mathrm{Zn}$ content ranged between 15.3 to $58.4 \mathrm{mg} \mathrm{kg}^{-1}$ (Gregorio et al. 2000), however due to milling, $\mathrm{Zn}$ content decreased to $12 \mathrm{mg} \mathrm{kg}^{-1}$ in polished rice (Barry 2006). Zinc deficiency is encountered in nearly $50 \%$ of the cereal-grown

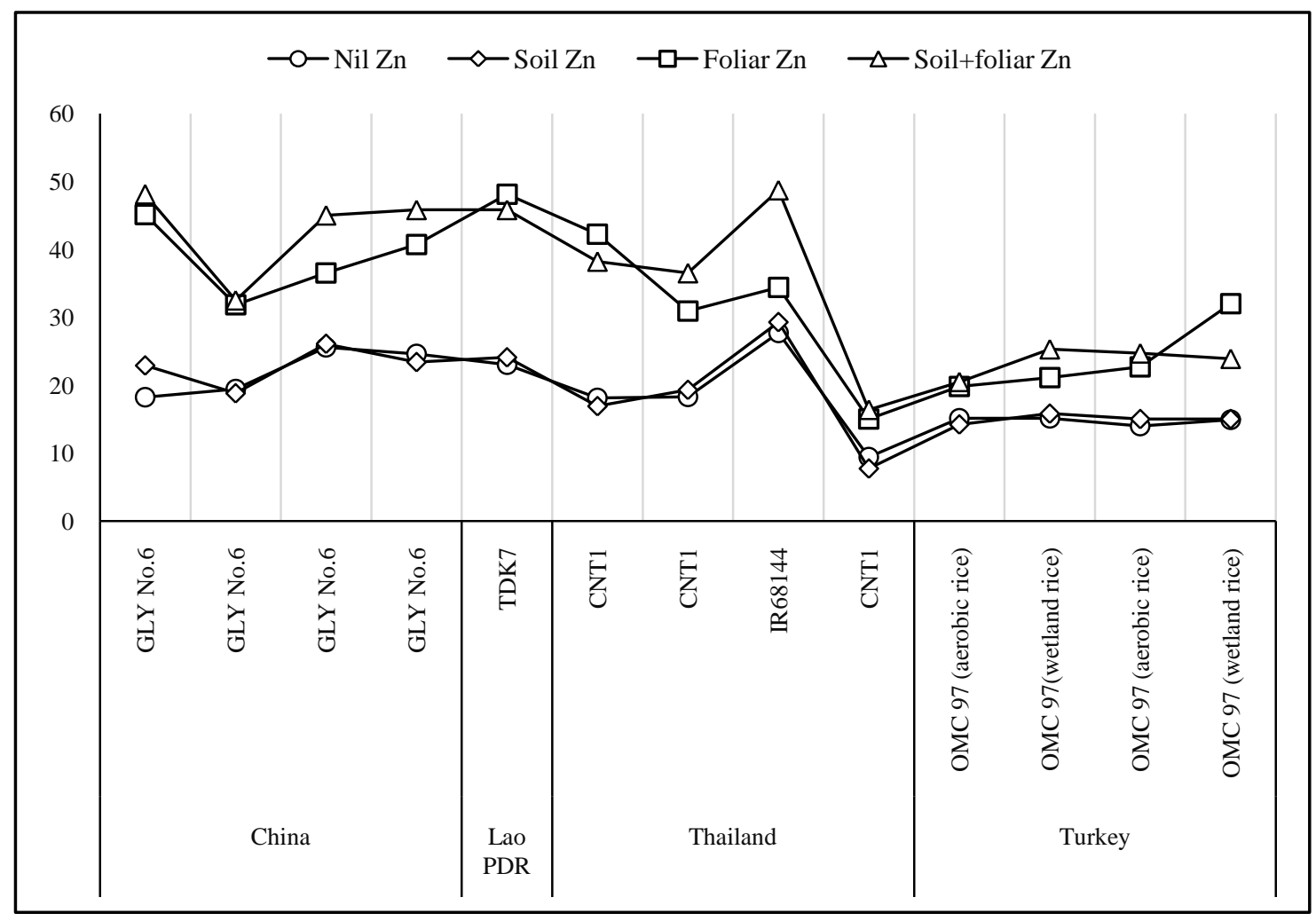

Figure 1 Zinc concentration $\left(\mathrm{mg} \mathrm{kg}^{-1}\right)$ in un-husked grain of different varieties of rice grown with different $\mathrm{Zn}$ fertilizer treatments in 4 countries (Phattarakul et al., 2012)

Journal of Experimental Biology and Agricultural Sciences http://www.jebas.org 
Table 2 Effect of different agronomic management approaches in increasing $\mathrm{Zn}$ concentrations

\begin{tabular}{|c|c|c|c|}
\hline Treatments & \multicolumn{2}{|c|}{ Percent increase over control } & Source \\
\hline \multirow{3}{*}{$0.5 \% \mathrm{ZnSO}_{4} .7 \mathrm{H}_{2} \mathrm{O}$ foliar spray at stem + booting stage of wheat } & $80 \mathrm{~kg} \mathrm{~N} \mathrm{ha}^{-1}$ & $\begin{array}{l}59.37 \% * \\
82.6 \% * *\end{array}$ & \multirow{17}{*}{ Cakmak et al., (2010) } \\
\hline & $240 \mathrm{~kg} \mathrm{~N} \mathrm{ha}^{-1}$ & $56.75 \% *$ & \\
\hline & & $44.82 \% * *$ & \\
\hline \multirow{4}{*}{$0.5 \% \mathrm{ZnSO}_{4} .7 \mathrm{H}_{2} \mathrm{O}$ foliar spray at booting + milk stage of wheat } & $80 \mathrm{~kg} \mathrm{~N} \mathrm{ha}^{-1}$ & $75 \% *$ & \\
\hline & & $113.04 \%$ ** & \\
\hline & $240 \mathrm{~kg} \mathrm{~N} \mathrm{ha}^{-1}$ & $51.35 \% *$ & \\
\hline & & $89.65 \% * *$ & \\
\hline \multirow{3}{*}{$0.5 \% \mathrm{ZnSO}_{4} .7 \mathrm{H}_{2} \mathrm{O}$ foliar spray at milk + dough stage of wheat } & $80 \mathrm{~kg} \mathrm{~N} \mathrm{ha}^{-1}$ & $78.12 \% *$ & \\
\hline & $240 \mathrm{~kg} \mathrm{~N} \mathrm{ha}^{-1}$ & $\frac{91.30 \% * *}{72.97 \% *}$ & \\
\hline & & $75.86 \% * *$ & \\
\hline \multirow{4}{*}{$\begin{array}{c}0.5 \% \mathrm{ZnSO}_{4} .7 \mathrm{H}_{2} \mathrm{O} \text { foliar spray at booting }+ \text { anthesis }+ \text { milk stage } \\
\text { of wheat }\end{array}$} & $80 \mathrm{~kg} \mathrm{~N} \mathrm{ha}^{-1}$ & $81.25 \% *$ & \\
\hline & & $130.43 \%$ ** & \\
\hline & $240 \mathrm{~kg} \mathrm{~N} \mathrm{ha}^{-1}$ & $75.67 \% *$ & \\
\hline & & $106.89 \% * *$ & \\
\hline \multirow{3}{*}{$\begin{array}{c}0.5 \% \mathrm{ZnSO}_{4} .7 \mathrm{H}_{2} \mathrm{O} \text { foliar spray at stem }+ \text { booting }+ \text { milk }+ \text { dough } \\
\text { stage of wheat }\end{array}$} & $80 \mathrm{~kg} \mathrm{~N} \mathrm{ha}^{-1}$ & $103.12 \% *$ & \\
\hline & & $143.47 \% * *$ & \\
\hline & $240 \mathrm{~kg} \mathrm{~N} \mathrm{ha}^{-1}$ & $\begin{array}{c}89.18 \% * \\
117.24 \% * *\end{array}$ & \\
\hline \multirow{3}{*}{ Soil Zn @ $50 \mathrm{~kg} \mathrm{ZnSO}_{4} .7 \mathrm{H}_{2} \mathrm{O} \mathrm{ha}^{-1}$} & $5.7 \%$ in $\mathrm{u}$ & sked rice & \multirow{9}{*}{ Phattarakul et al., (2012) } \\
\hline & $2.4 \%$ in & wn rice & \\
\hline & $0.9 \%$ in & ite rice & \\
\hline \multirow{3}{*}{ Foliar Zn@0.5\% ZnSO $4.7 \mathrm{H}_{2} \mathrm{O}$ solution } & $65.5 \%$ in $\mathrm{c}$ & usked rice & \\
\hline & $24.7 \%$ in & own rice & \\
\hline & $10.4 \%$ il & hite rice & \\
\hline \multirow{3}{*}{ Soil + foliar Zn application } & $73.6 \%$ in $\mathrm{c}$ & asked rice & \\
\hline & $31.9 \%$ in & own rice & \\
\hline & $15.1 \%$ il & hite rice & \\
\hline Soil application@20 kg ZnSO $4.7 \mathrm{H}_{2} \mathrm{O} \mathrm{ha}^{-1}$ & $17 \%$ in & wn rice & \multirow{2}{*}{ Saha et al., (2013) } \\
\hline $\begin{array}{l}\text { Soil + foliar application (2 sprays at pre flowering and grain } \\
\text { formation stage) @ } 0.5 \% \mathrm{ZnSO}_{4} .7 \mathrm{H}_{2} \mathrm{O} \text { solution }\end{array}$ & $95 \%$ in & wn rice & \\
\hline \multirow{2}{*}{$\begin{array}{c}\text { Alternate wet and dry cycle } \\
\text { (here increase is in respect of continuous flooding treatment) }\end{array}$} & 2.0 to $3.9 \%$ & brown rice & \multirow{8}{*}{ Wang et al., (2014) } \\
\hline & 13.8 to $15.5 \%$ & polished rice & \\
\hline \multirow{2}{*}{$\mathrm{ZnSO}_{4} .7 \mathrm{H}_{2} \mathrm{O}\left(5 \mathrm{mg} \mathrm{kg}^{-1}\right)$} & $10.6 \%$ in & wn rice & \\
\hline & $6.3 \%$ in $\mathrm{p}$ & hed rice & \\
\hline \multirow{2}{*}{ Zn-EDTA (5 mg kg $\left.{ }^{-1}\right)$} & $7.5 \%$ in & wh rice & \\
\hline & $6.6 \%$ in & wh rice & \\
\hline \multirow{2}{*}{ Water regime $\times$ Zinc treatment interaction effect } & Not significa & brown rice & \\
\hline & Significant i & olished rice & \\
\hline
\end{tabular}

* Cukurova University Research Farm in Adana ** Black Sea Agricultural Research Institute in Samsun 


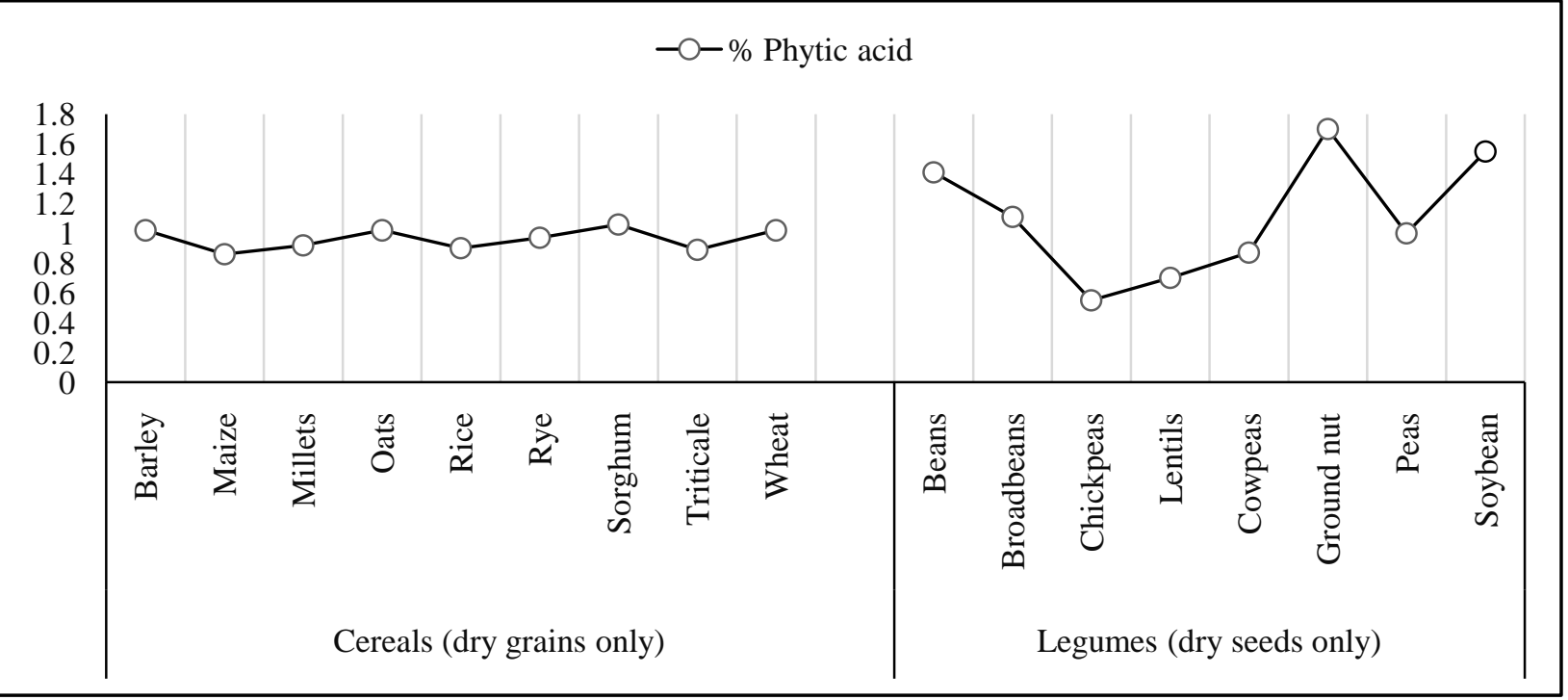

Figure 2 A global estimate of Phytic acid content (\%) of cereal grains and legume seeds (Lott et al., 2000)

areas in the world (Graham \& Welch, 1996; Cakmak, 2002) and as wheat provides nearly $50 \%$ of the daily calorie intake in rural region (Cakmak, 2004), the $\mathrm{Zn}$ enrichment strategies should focus not on the diets dominated by pulses, vegetables and fruits rather on diets dominated by cereals. Unlike wheat and barley, some of the bottleneck in $\mathrm{Zn}$ loading in rice crop are : Xylem-transported zinc is more important than phloem-transported zinc for zinc accumulation in the grains (Jiang et al., 2007) ; due to no xylem discontinuity in rice, $\mathrm{Zn}$ can be loaded directly from xylem in the vascular bundle to nucellar epidermis and aleuron cells (Krishnan \& Dayanandan, 2003) and low endosperm loading is not because of transport barriers but because of limited uptake (sink) capacity in the highly starch-filled endosperm cells (Stomph et al., 2009).

\section{Bioavailability of Fortified Zn}

The fraction of the micronutrient that is absorbed in the human intestine is more important than the total amount of micronutrient present in the edible part. Presence of various ant nutrient substances in the grains (phyic acid or phytin in whole legume seeds or cereals grains, fibres in whole cereal grain products, haemagglutinins (e.g. lectins) in most legumes and wheat) reduces the bioavailability of the metals (Graham et al., 2001). Phytic acid (or myo-inositol 1,2,3,4,5,6-hexakisphosphate) forms very stable complexes with mineral ions rendering them unavailable for intestinal uptake. As the phytic acid content of the diet increases, the intestinal absorption of zinc decreases (Flanagan, 1984). Besides its negative effects, phytic acid also assumed to play an important role in providing antioxidant properties, anticarcinogenic properties (Harland \& Morris, 1995), mineral cation storage in seeds, phosphorus homeostasis, buffering cellular phosphorus levels, etc. (Lopez et al., 2002) A global estimate of Phytic acid content of cereal and legume seeds are given in Figure 2.

There are various trials like cultured human intestinal cells (Caco2 cell model), animal models (e.g. rats, pigs, and poultry), and small scale human clinical trials (Underwood \& Smitasiri, 1999) which can be used to study how much amount of the metals present in the diet is actually absorbed by the body. However, this method of bioavailability test of micronutrients in numerous genotypes of staple foods crops is impractical (Graham \& Welch, 1996). A number of mathematical functions and regression analysis to model the observed relations between zinc absorption and various dietary components are also available from the WHO (WHO, 1996), the International Zinc Nutrition Consultative Group (IZiNCG, 2004), Wing et al. (1997) and Miller et al. (2007).

Total absorbed Zn per day (TAZ) was calculated as (Miller et al. 2007)

$$
T A Z=0.5 \times\left(\sqrt{\left(\sqrt{\left(A_{\max }+T D Z+K_{R} \times\left(1+\frac{T D P}{K_{p}}\right)\right)^{2}-4 \times A_{\max }+T D Z}\right)}\right)
$$

Where, Amax = maximum absorption (mill moles per day), 
$\mathrm{K}_{\mathrm{R}}=$ equilibrium dissociation constant of zincreceptor binding reaction (mill moles per day),

$\mathrm{K}_{\mathrm{P}}=$ equilibrium dissociation constant of $\mathrm{Zn}$ phytate binding reaction (mill moles per day),

$$
\begin{aligned}
& \mathrm{TAZ}=\text { total daily absorbed } \mathrm{Zn}, \\
& \mathrm{TDP}=\text { total daily dietary phytate and } \\
& \mathrm{TDZ}=\text { total daily dietary } \mathrm{Zn} .
\end{aligned}
$$

The values of the constants $A m a x, K_{P}$ and $K_{R}$ were revised as 0.091, 0.68 and 0.033, respectively (Hambidge et al., 2010).

The $\mathrm{Zn}$ absorption values predicted by this model were at par with the actually measured values in a labeled-Zn study in human (Rosado et al., 2009). Soil plus foliar Zn spray at heading reportedly increased estimated $\mathrm{Zn}$ bioavailability in wheat grains to the desired levels (Hussain et al., 2012). Foliar applied Znamino acid and $\mathrm{ZnSO}_{4}$ were found to be more effective than $\mathrm{Zn}$ EDTA and Zn-Citrate to cause a higher accumulation of bioavailable $\mathrm{Zn}$ in polished rice (Wei et al., 2012). Soil, foliar and soil + foliar $\mathrm{Zn}$ application were reported to decrease grain phytate concentration by 9\%,10\% and 14\%, respectively (Imran et al., 2015).

\section{Loss of Zn During Milling}

It has been reported (Lu et al., 2013) that $\mathrm{Zn}$ in the different parts of the grain are in order of: bran $>$ hull $>$ whole grain $>$ brown rice>polished rice. The concentration of $\mathrm{Zn}$ in the embryo and aleurone layer were around $150 \mathrm{mg} \mathrm{kg}^{-1}$ and $15 \mathrm{mg} \mathrm{kg}^{-1}$ in the endosperm (Ozturk et al., 2006).Tissue location-specific $\mu$-XRF mapping of rice grains also showed considerably more $\mathrm{Zn}$ concentration in the embryo, aleurone layer and hull tissues than endosperm and $43 \%$ of the total $\mathrm{Zn}$ were removed by the milling process (Lu et al., 2013). Consequently, consumption of milled cereal products may result in reduced $\mathrm{Zn}$ supply to the body. Therefore, emphasis should also be given on more $\mathrm{Zn}$ partitioning to seed endosperm and thereby curbing loss of $\mathrm{Zn}$ along with $\mathrm{Fe}$ and other essentials during processing. Effect of milling time on percent $\mathrm{Zn}$ loss from three different varieties is shown in Figure 3.

\section{Organisations Working in the Field of Biofortification of Micronutrients}

Harvest Plus, launched in 2004, as a follow up the Consultative Group for International Agricultural Research (CGIAR) micronutrients project is leading the development of biofortified varieties of different crops. Various Institutes which have responsibility to actively collaborate the Harvest Plus Programme are Africa Rice Center; Bioversity International, International Center for Tropical Agriculture; International Center for Maize and Wheat Improvement; International Potato Center; International Center for Agricultural Research in the Dry Areas; International Crops Research Institute for the Semi-Arid Tropics ; International Food Policy Research Institute ; International Institute of Tropical Agriculture and International Rice Research Institute. These Institutes receive fund under Harvest Plus Programme and have onus to develop micronutrients dense varities of staple food crops rich in micronutrients. The Harvest Plus scheme is funded by various agencies such as Asian

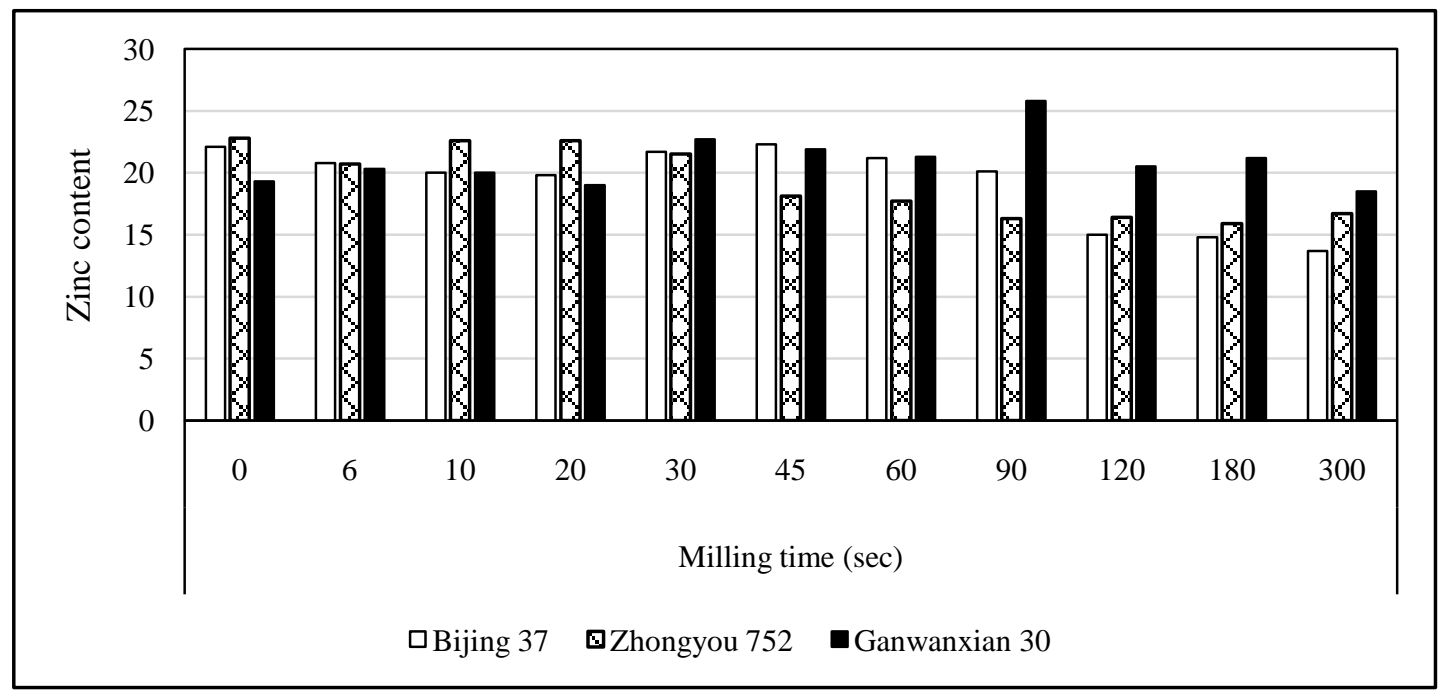

Figure 3 Effect of milling time on seed $\mathrm{Zn}$ contents $\left(\mathrm{mg} \mathrm{kg}^{-1}\right)$ of three rice cultivars (Liang, 2007)

Journal of Experimental Biology and Agricultural Sciences http://www.jebas.org 
Development Bank(ADB); Austrian Ministry of Finance; The Bill and Melinda Gates Foundation; International Life Sciences Institute (ILSRI); The International Fertilizer Group (IFG); Royal Danish Ministry of Foreign Affairs (RDMFA); Swedish International Development Agency(SIDA); Syngenta Foundation for Sustainable Agriculture (SFSA), U.K.; Department for International Development(DID); United States Agency for International Development(USAID); United States Department of Agriculture (USDA) and The World Bank (Harvest Plus, 2009).

Harvest Plus signed a memorandum of understanding with the Government of India in 2007 and is breeding for iron rich pearl millet and $\mathrm{Zn}$ rich wheat. They are also breeding for $\mathrm{Zn}$ rich rice in Bangladesh in $\mathrm{Zn}$ rich wheat in Pakistan. Harvest Zinc Fertilizer Project under Harvest Plus Program launched in April 2008 were employed in Brazil, China, India, Pakistan, Thailand, Turkey and Zambia. Agro Salud, for Latin American and Caribbean (LAC) countries, also united with Harvest Plus (Harvest Plus, 2012). The INSTAPA project focuses on the improvement of iron, zinc, and vitamin A content of millet, sorghum, maize and cassava based foods in sub-Saharan Africa as part of the 7th Framework Program of the European Commission (INSTAPA, 2015).

\section{Conclusions}

Zinc biofortification of staple food crops provides a novel strategy for fighting against micronutrient malnutrition in the developing countries. In an effort coordinated by the Harvest Plus Projects, CGIAR centers are taking a leading role in breeding crops for better nutrition. However, the successful performance of the biofortified crop depends primarily upon the soil nutrient availability. Therefore, optimizing the nutrient availability from the soil by employing proper agronomic practices is of paramount importance. Fertilizer strategies should aim at scheduling $\mathrm{Zn}$ application to maximize $\mathrm{Zn}$ loading in edible parts of cereals. Such varieties are needed with more $\mathrm{Zn}$ partitioning to the seed endosperm. In spite of large number of researches in increasing the $\mathrm{Zn}$ content in edible parts, a dearth of knowledge is available about the bioavailability of the metal to the consumer. So, $\mathrm{Zn}$ profiling of food crops along with $\mathrm{Fe}$ and other nutrients, antinutrients and promoters is need of the present day. Emphasis should also be given on curbing loss of $\mathrm{Zn}$ and Fe during processing of the food products. Therefore, it can be said that breeding program along with proper agronomic management will be helpful for implementation of biofortification as a real nexus in improving human health.

\section{Conflict of interest}

All the authors declares that there is no conflict of interest

\section{References}

Alloway BJ (2008a) Micronutrients and crop production. In: Alloway BJ (Ed.) Micronutrient deficiencies in global crop production, Springer, Dordrecht: Pp. 1-40.

Alloway BJ (2008b) Zinc in Soils and Crop Nutrition, IZA and IFA, Brussels, Belgium and Paris France.

Anonymous (2013) Pocket book on agricultural Statistics. Government of India, Ministry of Agriculture, Department of Agriculture and Cooperation. Directorate of Economics and Statistics, New Delhi.

Barry G (2006) High-iron and zinc rice. Available on http://www.knowledgebank.irri.org/rkb/health-andnutrition/highironand-zinc-rice.html access on 20.01.2014, IRRI.

Black RE (2003) Zinc deficiency, infectious disease and mortality in the developing world. Journal of Nutrition 133: 1485-1489.

Bouis HE, Welch RM (2010) Biofortification- a sustainable agricultural strategy for reducing micronutrient malnutrition in the global South. Crop Science 50: 20-32.

Broadley M, Brown P, Cakmak I, Rengel Z, Zhao F (2012) Function of nutrients: micronutrients. In: Marschner $\mathrm{P}$ (Ed.) Mineral Nutrition of Higher Plants, $3^{\text {rd }} \mathrm{Ed}^{\mathrm{n}}$, Academic Press London pp. 191-248.

Brouwer G (2010) Zinc essential for life. Director, Zinc Nutrient Initiative, Seminário de Micronutrientes, Sao Paulo Brasil November.

Cakmak I (2004) Identification and correction of widespread zinc deficiency in Turkey, A success story. In IFS Proceedings No. 552, International Fertiliser Society York UK pp. 1-28.

Cakmak I (2002) Plant nutrition research: Priorities to meet human needs for food in sustainable ways. Plant and Soil 247: $3-$ 24.

Cakmak I (2010) Biofortification of cereals with zinc and iron through fertilization strategy. $19^{\text {th }}$ World Congress of Soil Science, Soil Solutions for a Changing World, $1-6$ August, Brisbane, Australia.

Cakmak I, Kalayci M, Kaya Y, Torun AA, Aydin N, Wang Y, Arisoy Z, Erdem H, Yazici A, Gokmen O, Ozturk L, Horst WJ (2010) Biofortification and Localization of Zinc in Wheat Grain. Journal of Agricultural and Food Chemistry 58: 9092-9102.

Cakmak I (2000) Role of zinc in protecting plant cells from reactive oxygen species. New Phytologist 146: 185-205. 
Cakmak I (2008) Enrichment of cereal grains with zinc: Agronomic or genetic biofortification? Plant Soil 302: 1-17.

Cakmak I, Gulut KY, Marschner H, Graham RD (1994) Effect of zinc and iron deficiency on phytosiderophore release in wheat genotypes differing in zinc deficiency. Journal of Plant Nutrition 17: $1-17$.

Cunnane SC (1988) Role of zinc in lipid and fatty acid metabolism and in membranes. Progress in Food \& Nutrition Science 12: 15188.

Das, S, Green, A. (2013) Importance of zinc in crops and human health. Journal of the SAT Agricultural Research 11, 1-7.

FAO (2009) Food Insecurity in the World. Economic Crises Impacts and Lessons Learned. Food and Agriculture Organization of the United Nations Rome.

Flanagan PR (1984) A model to produce pure zinc deficiency in rats and its use to demonstrate that dietary phytate increases the excretion of endogenous zinc. Journal of Nutrition 114: 493-502.

Galera SG, Rojas E, Sudhakar D, Zhu C, Pelacho AM, Capell T, Christou P (2010) Critical evaluation of strategies for mineral fortification of staple food crops. Transgenic Research 19: 165-180.

Gartler J, Robinson B, Burton K, Clucas L (2013) Carbonaceous soil amendments to biofortify crop plants with zinc. Science of the Total Environment 465: 308-313.

Graham RD, Welch RM, Bouis HE (2001) Addressing micronutrient malnutrition through enhancing the nutritional quality of staple foods: principles, perspectives and knowledge gaps. Advances in Agronomy 70: 77-142.

Graham RD, Welch RM (1996) Breeding for staple-food crops with high micronutrient density: Working Papers on Agricultural Strategies for Micronutrients, No.3. International Food Policy Institute, Washington DC.

Gregorio GB, Senadhira D, Htut H, Graham RD (2000) Breeding for trace mineral density in rice. Food and Nutrition Bulletin 21: 382-386.

Guerinot ML (2000) The ZIP family of metal transporters, BBABiomembranes 1465: 190-198.

Hafeez B, Khanif YM, Saleem M (2013) Role of zinc in plant nutrition - A review. American Journal of Experimental Agriculture $3: 374-391$.

Hambidge KM, Miller LV, Westcott JE, Sheng X, Krebs NF (2010) Zinc bioavailability and homeostasis. American Journal of Clinical Nutrition 91: 1478S-1483S.
Harland BF, Morris ER (1995) Phytate: a good or a bad food component? Nutrition Research 15: 733-754.

Harvest Plus (2009) Breeding crops for better nutrition, International Food Policu Research Institute, Washington DC, USA.

Harvest Plus (2012) Harvest Plus Extends Reach in Latin America $\&$ the Caribbean, International Food Policu Research Institute, Washington DC, USA.

Hussain S, Maqsood MA, Rengel Z, Aziz T (2012) Biofortification and estimated human bioavailability of zinc in wheat grains as influenced by methods of zinc application. Plant Soil 361: 279-290.

Imran M, Kanwal S, Hussain S, Aziz T, Maqsood MA (2015) Efficacy of zinc application methods for concentration and estimated bioavailability of zinc in grains of rice grown on a calcareous soil. Pakistan Journal of Agricultural Sciences 52 : 169175.

INSTAPA (2015) Novel staple food-based strategies to improve micronutrient status for better health and development in subSaharanAfrica, available on http://www.instapa.org/everyone/ 2195 /5/0/20 access on 29 May 2010.

International Zinc Nutrition Consultative Group (IZiNCG) (2004) Assessment of the risk of zinc deficiency in populations and options for its control. In: Hotz C, Brown KH (Eds.) Food and Nutrition Bulletin 25United Nations University Press, Tokyo pp. S91-204.

Ishimaru Y, Suzuki M, Tsukamoto T, Suzuki K, Nakazono M, Kobayashi $\mathrm{T}$ (2006) Rice plants take up iron as an Fe3+-phytosiderophore and as Fe2+. The Plant Journal 45: 335-46.

Jiang W, Struik PC, Lingna J, Keulen HV, Ming Z, Stomph TJ (2007) Uptake and distribution of root-applied or foliar applied $65 \mathrm{Zn}$ after flowering in aerobic rice. Annals of Applied Biology 150: 383-391.

Kennedy G, Nantel G, Shetty P (2003) The scourge of "hidden hunger": global dimensions of micronutrient deficiencies. Food Nutrition \& Agriculture 32: 8-16.

Krishnan S, Dayanandan P (2003) Structural and histochemical studies on grain-filling in the caryopsis of rice (Oryza sativa L.). Journal of Biosciences 28, 455-469.

Kutman UB, Yildiz B, Ozturk L, Cakmak I (2010) Biofortification of durum wheat with zinc through soil and foliar applications of nitrogen. Cereal Chemistry 87: 1-9.

Liang J (2007) Iron, Zinc and Phytic Acid in Rice from China: Wet and Dry Processing towards Improved Mineral Bioavailability. 
$\mathrm{Ph}$.D. thesis submitted to the University of Wageningen University, Wageningen, The Netherlands.

Lindsay WL (1972) Zinc in soils and plant nutrition. Advance in Agronomy 24: 147-186.

Lindsay WL (1979) Chemical Equilibria in Soils, John Wiley \& Sons, New York.

Lopez HW, Leenhardt F, Coudray C, Remesy C (2002) Minerals and phytic acid interactions: is it a real problem for human nutrition? International Journal of Food Science \& Technology 37: 727-739.

Lott JNA, Ockenden I, Raboy V, Graeme D, Batten GD (2000) Phytic acid and phosphorus in crop seeds and fruits: a global estimate. Seed Science Research $10: 11-33$.

Lu L, Tian S, Liao H, Zhang J, Yang X, Labavitch JM, Chen W (2013) Analysis of Metal Element Distributions in Rice (Oryza sativa L.) Seeds and Relocation during Germination Based on XRay Fluorescence Imaging of Zn, Fe, K, Ca and Mn. PLoS ONE 8: $1-9$.

Mabesa RL, Impa SM, Grewal D, Beebouta SEJ (2013) Contrasting grain- $\mathrm{Zn}$ response of biofortification rice (Oryza sativa L.) breeding lines to foliar $\mathrm{Zn}$ application. Field Crops Research 149: 223-233.

Marschner H (1995) Mineral nutrition of higher plants, 2nd ed.,

London: Academic Press.

Mayer JE, Pfeiffer WH, Beyer P (2008) Biofortified crops to alleviate micronutrient malnutrition. Current Opinion in Plant Biology 11: 166-170.

McNulty TJ, Taylor, CW (1999) Extracellular heavy metal ions stimulate $\mathrm{Ca} 2+$ mobilization in hepatocytes. Biochemical Journal 339 : 555-561.

Meenakshi JV, Johnson N, Manyong VM, De Groote, H, Javelosa J, Yanggen D, Naher F, Gonzalez C, Garcia J, Meng E (2007) How cost effective is biofortification in combating micronutrient malnutrition? An ex-ante assessment. Harvest Plus 188-209.

Miller LV, Krebs NF, Hambidge KM (2007) A mathematical model of zinc absorption in humans as a function of dietary zinc and phytate. Journal of Nutrition 137: 135-141.

Miller WJ, Blackmon, DM, Gentry RP, Pitts WJ, Powell GW (1967) Absorption, excretion, and retention of orally administered zinc-65 in various tissues of zinc-deficient and normal goats and calves. Journal of Nutrition 92:71-8.
Moreau S, Thomson RM, Kaiser BN, Trevaskis B, Guerino, ML, Udvardi MK, Puppo A, Day D A (2002) GmZIP1 encodes a symbiosis-specific zinc transporter in soybean. Journal of Biological Chemistry 15: 4738-46.

Mortvedt JJ, Gilkes RJ (1993) Zinc fertilisers. In: Robson AD (Ed.) Zinc in soils and plants. Kluwer Academic Publishers, Dordrecht, Pp. 33-44.

Muthukumararaja TM, Sriramachandrasekharan MV (2012) Effect of zinc on yield, zinc nutrition and zinc use efficiency of lowland rice. Journal of Agricultural Sciences and Technology 8 : 551-561.

Nestel P, Bouis HE, Meenakshi JV, Pfeiffer W (2006) Biofortification of staple food crops. Journal of Nutrition 136: 1064-1067.

Ozturk L, Yazici MA, Yucel C, Torun A, Cekic C, Bagci A, Ozkan H, Braun HJ, Sayers Z, Cakmak I (2006) Concentration and localization of zinc during seed development and germination in wheat. Physiology Plantarum 128: 144-152.

Pfeiffer WH, McClafferty B (2007) Harvest Plus: breeding crops for better nutrition. Crop Science 47: S88-S105.

Phattarakul N, Rerkasem B, Li LJ, Wu L, H, Zou CQ Ram H, Sohu VS, Kang BS, Surek H, Kalayci M, Yazici A, Zhang FS, Cakmak I (2012) Biofortification of rice grain with zinc through zinc fertilization in different countries, Plant Soil 361: 131-141.

Prasad AS (1985) Clinical manifestations of zinc deficiency. Annual Review of Nutrition 5: 341-363.

Press release, Times of India, May 22, (2015). http:// timesofindia.indiatimes. com/india /Scientists-in-Chhattisgarhdevelop-high-zinc-rice-that-may-play-crucial-role-in-fightingmalnutrition access on 29 May 2015.

Ramesh SA, Shin R, Eide DJ, Schachtman DP (2003) Differential metal selectivity and gene expression of two zinc transporters from rice. Journal of Plant Physiology 133: 126-34.

Rosado JL, Hambidge KM, Miller LV, Garcia OP, Westcott J, Gonzalez K, Conde J, Hotz C, Pfeiffer W, Ortiz MI, Krebs NF (2009) The quantity of zinc absorbed from wheat in adult women is enhanced by biofortification. Journal of Nutrition 139: 1920-192.

Saha B, Saha S, Roy PD, Hazra GC, Das A (2013) Zinc fertilization effects on agromorphological and quality parameters of commonly grown rice. SAARC Journal of Agriculture 11(1): 105-120.

Shukla AK, Behera SK, Pakhare A, Chaudhari SK (2018) Micronutrients in soils, plants, animals and humans. Indian Journal of Fertilizers $14: 30-54$. 
Singh A, Shivay YS (2013) Residual effect of summer green manure crops and $\mathrm{Zn}$ fertilization on quality and $\mathrm{Zn}$ concentration of durum wheat (Triticum durum Desf.) under a Basmati ricedurum wheat cropping system. Biological Agriculture and Horticulture 29 : 271-287.

Singh MV (2009) Micronutrient nutritional problems in soils of India and Improvement for human and animal health. Indian Journal of Fertilizers 5: 11-26.

Singh MV (2010) Detrimental effect of zinc deficiency on crops productivity and human health. First Global Conference on Biofortification, Harvest Plus Washington USA.

Stein AJ, Nestel P, Meenakshi JV, Waim M, Sachdev HPS, Bhutta ZA (2007) Plant breeding to control zinc deficiency in India: how cost-effective is biofortification? Public Health Nutrition 10: 492-501.

Stomph TJ, Jiang W, Struik PC (2009) Zinc biofortification of cereals: rice differs from wheat and barley. Trends in Plant Science 14: $123-124$.

Underwood BA, Smitasiri S (1999) Micronutrient malnutrition: policies and programmes for control and their implications. Annual Review of Nutrition 19: 303-324.

Vidyavati SD, Sneha A, Katti SM (2016) Zinc- The Importance in Human Life. International Journal of Healthcare and Biomedical Research 4: 18-20.

Virk R, Senadhira D, Bebe S (2009) Iglesias, C. and Monasterio, I., Breeding for micronutrient density in edible portions of staple food crops: conventional approaches. Field Crop Research 60: 5780 .

Wang Y, Wei Y, Dong L, Lu L, Feng Y, Zhang J, Pan F, Yang Y (2014) Improved yield and $\mathrm{Zn}$ accumulation for rice grain by $\mathrm{Zn}$ fertilization and optimized water management. Journal of Biomedicine and Biotechnology 15: 365-374.

Waters BM, Renuka PS (2011) Moving micronutrients from the soil to the seeds: Genes and physiological processes from a biofortification perspective. Plant Science 180: 562-574.

Wei Y, Shohag MJ, Yang X (2012) Biofortification and Bioavailability of Rice grain zinc as affected by different forms of foliar zinc fertilization. PLoS ONE 7: e45428.

Welch RM (1995) Micronutrient nutrition of plants. Critical Reviews in Plant Sciences 14: 49-82.

White PJ, Broadley MR (2005) Biofortifying crops with essential mineral elements. Trends in Plant Science 10: 586-593.
White PJ, Broadley MR (2009) Biofortification of crops with seven mineral elements often lacking in human diets-iron, zinc, copper, calcium, magnesium, selenium and iodine. New Phytologist 182: 49-84.

WHO (1996) Food and Agriculture Organization (FAO), International Atomic Energy Association (IAEA). Trace elements in human nutrition and health. Geneva, WHO.

WHO (2007) UNICEF India, Children Issues. Global Database on Child Growth and Malnutrition in United Nations Administrative Committee on Coordination/Sub-Committee on Nutrition, Low Birth Weight, Nutrition Policy, Paper 18. http://www.who.int/nutgrowthdb/en/

Widodo Broadley, MR, Rose T, Frei M, Pariasca-Tanaka J, Yoshihashi T, Thomson M, Hammond JP, Aprile A, Close TJ, Ismail AM, Wissuwa M (2010) Response to zinc deficiency of two rice lines with contrasting tolerance is determined by root growth maintenance and organic acid exudation rates, and not by zinctransporter activity. New Phytologist 186: 400-14.

Wing KR, Wing AM, Sjöström R, Lönnerdal B (1997) Efficacy of a Michaelis-Menton model for the availability of zinc, iron and cadmium from an infant formula diet containing phytate. In: Fischer PWF, L'Abbé MR, Cockell KA, Gibson RS, (Eds.) Trace elements in man and animals 9: Proceedings of the Ninth International Symposium on Tracer Elements in Man and Animals; 1996, May 1924; Banff, Alberta, Canada. Ottawa: NRC Research Press p. 31-2.

Wissuwa M, Ismail AM, Graham RD (2008) Rice grain zinc concentrations as affected by genotype, native soil-zinc availability, and zinc fertilization. Plant Soil 306: 37-48.

Yilmaz A, Ekiz H, Torun B, Gultekin I, Karanlik S, Bagci SA, Cakmak I (1997) Effect of different zinc application methods on grain yield and zinc concentration in wheat grown on zinc-deficient calcareous soils in Central Anatolia. Journal of Plant Nutrition 20: $461-471$

Yoshida S, Tanaka A (1969) Zinc deficiency of the rice plant in calcareous soils. Soil Science and Plant Nutrition 15: 75-80.

Zalewski PD, Forbes IJ, Betts WH (1993) Correlation of apoptosis with change in intracellular labile Zn (II) using zinquin [(2-methyl8-p-toluenesulphonamido-6-quinolyloxy)acetic acid], a new specific fluorescent probe for Zn(II). Biochemical Journal 296: 403-408.

Zhang F, Romheld V, Marschner H (1989) Effect of zinc deficiency in wheat on the release of zinc and iron mobilizing root exudates. Z. Pflanzenernahr. Bodenk 152: 205-210. 